\title{
THE ORIGINS OF JEWISH BELIEFS IN ANGELS ${ }^{1}$
}

\author{
Annette Evans \\ Research Fellow \\ Afroasiatic Studies Sign Language and Language Practice \\ Free State University
}

\begin{abstract}
This article suggests that Jewish beliefs about the functioning of angels originated in two threads: the unique ancient Egyptian institution of the king as the divine son of God (which includes solar worship), and the concept of the Divine Council, in which the supreme God is the king of the gods. The method of investigation involved a close reading, combined with a History of Religions methodology, of texts displaying marked angelological content. Certain motifs, especially "throne" and "sun/fire", which were identified as characteristic of angelic functioning, were compared across a broad spectrum of texts. In this way the diachronic development of major angelological motifs as well as the synchronic connections (in terms of angelological motifs) between the respective cultural contexts became apparent. In a following article, it is suggested that the intellectual abstractions of Hellenism effected the transition to the reception of the concept of Christianity within a monotheistic framework.
\end{abstract}

\section{Keywords: Angels, Polytheism, Merkebah Throne, Qumran, Egypt}

The only recent examination of the development of Jewish belief in angels is by Mach (1992), who noted (1999:42), that often when Jewish identity underwent a crisis "exalted angels or the like" were introduced. Consequently this work examines the connection between cultural context and Jewish belief in angels. Dever (2002:28) registered "a passionate plea for a renewed commitment to history, not theology, in pursuing ancient Israelite religion, for a return of the basic evolutionary, comparative, and ecumenical approach of Religionsgeschichte..." The basic methodological assumption of this study is that the apperceptive mass ${ }^{2}$ of the respective authors will be detectable through a close ${ }^{3}$ reading of their texts if this is supplemented by a History of Religions study, ${ }^{4}$ and that this

\footnotetext{
This article is based on the first half of my unpublished dissertation (Evans 2007). The material is based on work supported financially by the National Research Foundation.

2 The apperceptive mass of the author has to be taken into account, i.e. the accumulation of ideas already possessed, derived from such sources as earlier texts or oral traditions, and these inevitably include interaction with other cultures. Corsini (2002:61) defines apperceptive mass as "a group of present ideas, influential in determining what new ideas shall gain admission to consciousness and in what way new objects shall be perceived".

3 By this term a careful reading, not necessarily the technical term employed in a literary-critical method, is meant.

4 Cf Lategan (1992 III:153): "For an adequate understanding of the text, analysis of its structure has to be complemented by the historical study of the world behind the text". The original Religionsgeschichtliche Schule, centred at Göttingen from the late 1880's to the 1930's, investigated "the multifaceted religious movements which surround Christianity" in a purely historical manner (Chapman 2000:257), thus recognising that the Bible had to be understood in the context of the discoveries that were being made in the broader setting of Egyptian, Babylonian and Hellenistic religions. It was seen that Christianity had many intellectual
} 
will enable a tracing of the historical development of angelological ideas. A careful reading, combined with a History of Religions methodology, was done of a broad selection of ancient angelological texts ranging from ca. $600 \mathrm{BCE}$ to ca. $200 \mathrm{CE}$. In Chart A the selected texts are placed approximately in their historical context. After careful reading of all the texts, certain motifs, especially "throne" and "sun/fire", were identified as characteristic of descriptions of angelic functioning, and these motifs were compared across the entire spectrum of texts. In this way the diachronic development of major angelological motifs as well as the synchronic connections (in terms of the identified angelological motifs) between the respective cultural contexts became apparent.

After reviewing the distribution of angelological motifs in all the texts, it appeared that Jewish angelology originated in two separate threads: the Divine Council and solar worship (which is usually associated with fire and/or light). Overwhelming evidence is now extant associating sun and fire with God/El/Elohim during Iron age IIB (925-720/700 BCE) as creator, protector, and also expressing his might and majesty. Keel and Uehlinger $(1998: 255,275)$ present iconographical evidence to demonstrate the connection of Egyptian Solar Worship to the Israelite/Judite Royal throne. These scholars have gone so far as to claim $(1998: 277,279)$ that by the eighth century Yahweh was conceived of as the actual sun god. The Chester Beatty text iv, lines 269, 293, 297-8 describe the sun god as the "great shepherd" and "brightest source of life for all" (Nel 2005:95). Nel relates the shepherd metaphor for the king in Egypt to the "exertion of justice" and "the bodily incarnation of the divine".

The ancient Egyptian connection as the possible source of the solar worship has implications which form the basis for an hypothesis about a pattern of mediation between heaven and earth which I see as having developed over the course of the time-span under discussion. Ancient Egypt presents a unique situation because in Egypt, unlike any of the other ancient cultures, kingship was a divine institution (Grabbe 2001:29-31; Silverman 1995:61). Through the ritual of coronation, the living pharaoh was conceived of as a god incarnate (Horus), and (amongst other things), the "son of Re" (the sun disc). The association of the sun disc with the pharaoh highlighted his cosmological power. Tobin (1959:210) describes the pharaoh as "himself a mythic expression of the divinity of the realm of the beyond". In theory it was the king himself who was the true priest of the Egyptian cults, the "genuine intermediary between man and the gods, and hence only he who had the priestly character within him in virtue of his very nature and his office" (Tobin 1989:99).

Evidence of the inherent ambiguity of Jewish angelology ${ }^{5}$ is apparent in Psalm 82, one of the oldest and best preserved Psalms, where the context is the ancient polytheistic idea of the Divine Council. El is portrayed as the supreme judge in the texts from Ugarit, but in Psalm 82 the supreme judge is named "Elohim", albeit in the "Council of El".6 Elohim is surrounded by a council of gods who appear to be his servants and messengers. To the Greek translator the terms "Elohim" and "El" were interchangeable, both meaning "God", but the ambiguity of the plural form אלהים and the term "sons of the Most High"

links with contemporaneous religions, for example Hellenistic Judaism, and thus the continuity between the Bible and the culture of the Ancient Near East was emphasised. Texts were only to be interpreted against their own cultural contexts - "their location within the stream of history" (Boring 1996:21).

$5 \quad$ For example Gen 16:7-13; Gen 18; Gen 22; Gen 31:11-13; Gen 32; Ex 3:2-6; Num 22; Jdg 2:1 (MT 6:11-22; Ez 8:2; Mal 3:1

6 This portrayal of God as the supreme judge is echoed in Isa 6; I Kings 22:19-22; Dan 7:9, and in I Enoch 14:3-16:3. 
becomes an angelological issue. The polytheistic undertones of Psalm 82 go some way to explain the later resistance of the rabbis to the understanding of the term "sons of God" as fused with the concept of angels. Levine (1988:65) confirms the marked "anti-angel" movement in Pharasaic theology, whereby they strove "to eliminate the concept of a heavenly pantheon". This struggle to establish and maintain Jewish identity as monotheistic, complicates the search for the origins and development of Jewish angelology.

\section{The Merkebah Throne}

The blending of the two concepts of the Divine Council where the supreme God is surrounded by lesser gods or messengers, and the king associated with sun or fire, is perceptible in Ezekiel 1 and 10. Because the MT as presented in Biblica Hebraica Stuttgartensia is based on the tenth century CE Codex St. Petersburg which is so late, comparisons are made with the Old Greek version of the Septuagint. The Septuagint, being a translation from the Hebrew, is especially useful because it reflects the religious needs and exegetical perceptions of Alexandrian Jews in the third and second centuries BCE. However, it is striking that Ezekiel 1:14 and 10:14 have not been included in the Old Greek reconstruction by Ziegler, but these two angelologically charged verses are attested amongst the Qumran texts (ca. $100 \mathrm{BCE}-60 \mathrm{CE}$ ). In this study, Codex Alexandrinus is referred to for the two missing verses in Ezekiel 1 and 10. ${ }^{7}$

The theophany starting at Ez 1:4 describes a unit of four "living beings" which uphold the throne of God. The description includes a fire "flashing here and there" (מתלקחת). The strange word hashmal (החשמל) is mentioned, translated in the LXX as ๆ’ $\lambda$ éкpou (electron), in the RSV as bronze, and in the KJV as amber. Electrum, a naturally occurring mixture of gold and silver, was being manufactured into amulets at least as early as the Old Kingdom (2649-2150 BCE) (Andrews 1994:105). Strudwick (2005:73) records that "electrum" was used as early as 2500 BCE in Egypt to make a pharaonic statue. Greenberg (1983:43) states that hashmal "belongs to the heart of the vision of Majesty". It has been likened to "the brilliant and blinding light of the sun", and came to be regarded as endowed with holy and dangerous properties. Interestingly, it was already known in hellenistic times that amber has static electricity. In modern Hebrew hashmal means electricity. ${ }^{9}$

Verses 15 to 22 describe the ophanim, האופנים, which appear to be four huge wheels each standing beside each of the four living beings, and each constructed as if it were a "wheel within a wheel". The description of the ophanim changes in Ezekiel 10:2a. Suddenly לגלגל, the Aramaic word for wheel, is used, which the Old Greek translaterates as $\Gamma \epsilon \lambda \gamma \in \lambda($ galgal):

7 The papyrus discoveries of recent years witness to the very ancient text which Codex Alexandrinus has preserved in parts despite its assimilation to other recensions (Jellicoe 1968:187).

8 Hitp. Participle of לקח ("fire flashing continually"). The meaning of מתלקחת is uncertain, but here and at the only other place where it occurs in the OT, in Exodus 9:24, in a magical context, a supernatural fire is denoted - perhaps fire "burning in the air as a fiery mass without having an object onto which it has caught" (Greenberg 1983:43). It is rendered in LXX by the participle $\epsilon^{\prime} \xi \alpha \sigma \tau \rho \alpha ́ \pi \tau o \nu$, a neologism derived from '́ $\xi \alpha \sigma \tau \rho \alpha ́ \pi \tau \omega$ "to flash as with lightning".

9 Plato, in Timaeus 80C, in a cosmological context, gives a remarkable description of the functioning of

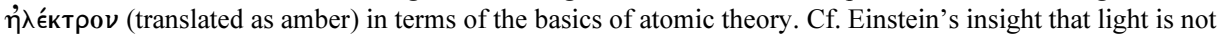
only a wave but a particle such as an electron (Isaacson 2007:156). 
ויאמר אל־האיש לבש הבדים ויאמר בא אל־בינות לגלגל אל־תחת לכרוב

And he said to the man clothed in linen, "Go in among the whirling wheels underneath the cherubim".

Clarity about the significance of the whirling wheels can only be gained if the symbolism of the galgal is understood. On a macro-cosmological level Uehlinger and Trufaut (2001:154, 155) find Babylonian symbolism in the wheel as a cosmic halo or divine astral symbol as found in Neo-Assyrian cylinder seals of the $7^{\text {th }}$ to $8^{\text {th }}$ Century. They $(2001: 158)$ suggest that the whole system of moving wheels may actually be interpreted as a kind of stellar system related to the celestial bodies, and that this vision is a reflection on the movement of astral spheres.

In spite of the fact that one expects that wheels are for turning, at Ez 1:8b, 9 and 17 and in Ezekiel 10:11 and 22, it is repeatedly stressed that the living beings do not turn in their

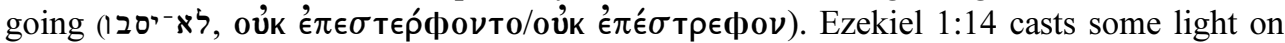
this peculiarity: "And the living creatures darted to and fro, like a flash of lightning"

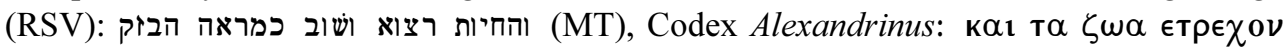

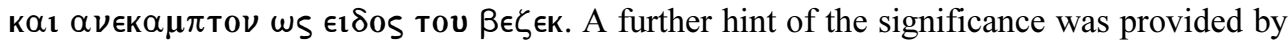
Jerome (ca. 347-419 CE), who suggested that the absence of Ez 1:14 in the Old Greek is because the translator deliberately suppressed the verse because of the tensions with verses 9, 12 and 17, where it is stated that the living beings did not turn as they went (Lust 1999:17). At very least the emphatic denial of turning in these verses and in Ez 10:11a and $\mathrm{b}, 16 \mathrm{~b}$ indicates that turning or not turning is a very important concept. The description in Ezekiel 1:14 is remarkably close to several descriptions of the "going out and returning" movement of the messengers (Iynges) in the Neoplatonic Chaldean Oracles (see my article to follow). ${ }^{10}$ The association with the Iynges would have been a problem to the rabbis because of the association with "magic" in the Chaldean Oracles, where "turning" or "whirling" is a part of the process of divination. ${ }^{11}$

\section{Angelological Aspects in Texts from Qumran}

The angelic or messenger content of Ez 1:14 in terms of "darting to and fro" or literally "running and returning", related to the functioning of the whirling wheels, becomes clearer when the descriptions of this activity are examined in certain texts found at Qumran. The allusions to galgal in the Qumran texts which we look at briefly, strengthen the possibility that this angelological motif could be connected to the concept of darting to and fro in Ez 1:14, by virtue of the association of "whirling". Thus Ez 1:14 may have been deliberately excluded because of divinatory associations. I argue that the absence of this verse in the Old Greek, yet attested at Qumran, is significant, and that it conveys angelological content

10 For example: "these ineffable causes [the Iynges] are called 'swift' by the oracles, and hastening away from the Father hasten again back towards him" (Frg. 87 Proclus, 410 to $485 \mathrm{CE}$ ).

11 In the RSV the idea of turning is re-inforced by the word "whirling" - in spite of all the protest against turning, the translator found it necessary to specify that the wheels are "turning" after all. In addition, the phrase "in my hearing" seems to reinforce the importance of this term, as though it is almost unbelievable. NRSV and NETS have "wheel work" for galgal where RSV has "whirling wheels", but I regard their translation as an attempt at harmonization with the motif of "not turning", especially in view of their translation of oúк є̇ $\epsilon \dot{\epsilon} \sigma \rho \epsilon \Theta o \nu$ with "without veering". NETS, the New English translation of the Septuagint, is to be found at http://ccat.sas.upenn.edu/nets/edition/iezek.pdf (Cook 2002). 
which is vital for the understanding of the origins of Jewish angelology. ${ }^{12}$ The hints of "magical" activity in Ez 1 and 10 are strengthened in the following texts found at Qumran.

The Aramaic fragments of the Book of Watchers are found in 4Q 201-202, 4Q 204-206, and 4Q Enoch a Ar. Milik's translation (1976:199-200) of I Enoch 14.18 and 19 describes the wheels as follows:

And it was shown to me and I saw in it a lofty throne, and its appearance]

[was like crystal -glass,

and its wheels (גלגליהו) were like the disc (כגלגל) of the shining sun, and its sides] were cherubim.

[And from beneath the throne came forth] streams of [fire, and I could not look.

Here there is an interesting connection from the galgal to the ancient Near Eastern concept of the sun disk. ${ }^{13}$ Enoch's vision of the throne of God has the clearly angelological motifs of streams of fire, and galgal, but interestingly, not "do not turn". The absence of the "do not turn" motif may indicate that divinatory practices were not regarded as undesirable in the context from which 1 Enoch Book of Watchers arose. ${ }^{14}$

Four copies of Daniel, virtually identical to the MT, were found at Qumran. In Daniel 7 the angelological connotations of "streams of fire" are confirmed. The angelologically laden verses MT Dan 7:9b and 10a are translated in the RSV as "his throne was fiery flames, its wheels (גלגלוהי) were burning fire. A stream of fire issued and came forth from before him". 15

The Songs of the Sabbath Sacrifice serve to clarify the significance of both galgal and "rivers/streams of fire". ${ }^{16}$ The fragment containing Song Seven (4Q403 Frg. 1ii) is clearly based on Ezekiel 1 and 10, but describes the phenomenon of angelic function at the throne of God in a completely different format. There is a strong sense of the immediacy of the angelic activity, especially in line 6, and this actually serves to clarify some of the puzzling content in Ezekiel 1 and 10. Line 6 reads: "from between them go[d-1]ike beings run like the appearance of coals of fire". Line 9 has another variation: "and divine spirits, shapes of flaming fire round about it $1[$ ". There are frequent references to fire in connection with spirits which are moving in the shrine or sanctuary of the "King" or throne of God. Line 7 reinforces the association of movement with fire: "moving round about, spirits of holiest holiness [". 4Q405 Frg. 15ii-16 lines 2-3a contain the motif of "rivers of fire"; "and rivers of fire [ ].[ ].. ... [ ].[ the appearance of flames of fire[". This motif crops up again in Song Eleven, where, in lines 9 and 10, a movement of going out and returning, which gives the appearance of "streams of fire" is indicated:

12. Sanderson (1997:211) presents the following information about Ezekiel 1:14 and Ezekiel 10:14: 4Q Ezekiel b Col IV Frgs 5-6 lines 1 and 2, have a space (illegible due to damage) where Ezekiel 1:14 and 15 would have been, and continues on the next line with part of Ez 1:16. 4QEzekiel a Frg. I lines 13 and 14 have the

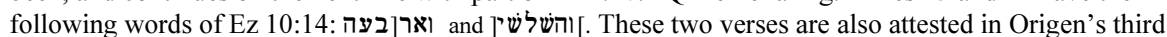
century Hexaplaric Opus. Philip Alexander $(2006: 6,72,129)$ emphasises that the texts from Qumran reflect not only the beliefs about angels in the Qumran community (c 100 BCE-70 CE), but the broader Jewish population at that time.

13 Keel and Uehlinger (1998:140) demonstrate that the sun disk, together with other cosmological symbols, is well represented in Israelite and Judahite iconography.

14 García Martínez, in his recent article "Magic in the Dead Sea Scrolls" has noted that though the Qumran community knew of the biblical prohibition against magic, exorcism and divination were actively used.

15 The NETS trans. of the OG reads: "The throne was like a flame of fire shooting out, and a stream of fire went out before him".

16 The translations quoted below are by Carol Newsom (1998). 
And the splendour of the luminous platform do they sing (which is) beneath His glorious seat. And when the wheels move, the holy angels return. They go out from between its glorious [h]ubs (galgali). Like the appearance of fire (are) the most holy spirits round about, the appearance of streams of fire like hashmal. And there is a [ra]diant substance.

This passage clarifies and confirms that "streams of fire" represents a constant stream of angels (i.e. holy spirits/god-like beings) going forth from, and returning to, the throne. Newsom (1998:352) recognises here that the paired verbs of line $9 \mathrm{~b}$ and drawn from a form of Ez 1:14 (MT רצוא ושוב) like the Codex Alexandrinus version

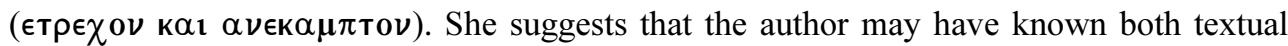
traditions, and I certainly agree. It is interesting that, as at I Enoch 14.19 and Dan 7:9b $10 \mathrm{a}$, the wheels of the divine throne (called galgali there, as they are here), are also associated with streams of fire. Perhaps the "hubs" (actually galgali) are themselves the "angelic spirits" "running and returning" at high speed, therefore creating the appearance of streams of fire flowing out from the wheels. This description seems to me to express the essence of mediator activity arising from the throne of God, as conceived of in the texts we have dealt with, and I would suggest that the germ of this description is already contained in $\mathrm{Ez} 1: 14$.

\section{Conclusion}

The issue of the original presence or absence of Ezekiel 1:14 is crucial to the understanding of the source of Jewish angelology. Taking a lead from Jerome, I hypothesize that the "not turning" was to make a distinction between the angelological content of Ezekiel 1 and associated and "magical" or at least divinatory practices in the social context from which this text was produced. ${ }^{17}$ It appears that over the eight hundred year time-span that this study covers, Jewish angelology indeed originated in polytheistic ideas of the Divine Council, combined with Egyptian solar worship, often associated with fire and/or light. I would suggest that the puzzling "not turning" motif which appears first in Ezekiel 1 and 10 was to make a distinction between associated and current "magical" or at least divinatory practices in the social context from which this text was produced. Thus Ez 1:14 may have been eliminated by conservative LXX translators because of their desire to suppress Jewish angelology because of insight into its "magical" aspects (cf Rofe 1979:xiii). The onset of Hellenism stimulated new ways of thinking about mediation between God and mankind. My article to follow suggests that the characteristic ambiguity of Jewish angelology functioned "fruitfully" (Ashton 1998:79), in that these angelological motifs became incorporated into a manifestation of a supreme monotheistic authority.

7 Bowker (1969:38) and Halperin (1982:363) observe that the Greek translators of Ezekiel (possibly in ca. $150 \mathrm{BCE}$ ), show a concern with extracting, or concealing the implications of the sacred text, as do the Targums. Morray-Jones (1992:14) has also noted this tendency. 


\section{BIBLIOGRAPHY}

Alexander, PS 2006. The Mystical Texts. Songs of the Sabbath Sacrifice and Related Manuscripts. London/New York: T \& T Clark International.

Andrews, C 1994. Amulets of Ancient Egypt. London: British Museum Press.

Ashton, J 1994. Studying John: Approaches to the Fourth Gospel. Oxford: Clarendon Press.

Bremmer, JN and Veenstra, JR (eds.) 2002. The Metamorphosis of Magic from Late Antiquity to the Early Modern Period. Groningen Studies in Cultural Change 1. Leuven: Peeters.

Cook, J 2002. Bible and Computer. The Stellenbosch AIB Conference. Proceedings of the Association Internationale Bible et Informatique "From Alpha to Byte", University of Stellenbosch 17-21 July, 2000. Leiden: Brill.

Corsini, RJ 2002. The Dictionary of Psychology. London: Brunner-Routledge.

Dever, WG 2002. Theology, Philology, and Archeology, in Gittlin, 1-29.

Evans, AHM 2007. The Development of Jewish Beliefs in Angels. Egyptian and Hellenistic Connections. Ca 600 BCE-200 CE. Unpublished dissertation, University of Stellenbosch.

García Martínez, F 2002. Magic in the Dead Sea Scrolls in Bremmer and Veenstra, 13-33.

García Martínez, F 2003. Iranian Influences in Qumran? In McNamara 2003, 37-49.

Gittlin, BM (ed.) 2002. Sacred Time, Sacred Place. Archeology and the Religion of Israel. Winona Lake"Eisenbrauns.

Grabbe, LL (ed.) 2001. Did Moses Speak Attic? Jewish Historiography and Scriptures in the Hellenistic Period. Sheffield: Sheffield Academic Press.

Greenberg, M 1983. Ezekiel 1-20. Anchor Bible Commentary. NY: Doubleday.

Isaacson, W 2007. Einstein. His Life and Universe. New York/London/Toronto/Sydney: Simon \& Schuster.

Jellicoe, S 1968. The Septuagint and Modern Study. Oxford: Clarendon Press.

Keel, O and Uehlinger, C 1998. Gods, Goddesses, and Images of God in Ancient Israel. Trans. TH Trapp 1998. Fortress Press: Minneapolis.

Levine, E 1988. The Aramaic Version of the Bible. Berlin/NY: Walter de Gruyter.

Lust, J 1999. Notes to the Septuagint. Ezekiel 1 and 2. ETL, Vol 75, 5.

Mach, M 1992. Entwicklungsstadion des jüdischen Engelglaubens in vorrabbinischer Zeit. Tübingen: Mohr.

Mach, M 1999. Concepts of Jewish Monotheism during the Hellenistic Period, in Newman et al 1999, 21-42.

McNamara, M (ed.) 2003. Apocalyptic and Eschatological Heritage. The Middle East and Celtic Realms. Dublin: Four Courts Press.

Milik, J T 1976. The Books of Enoch. Aramaic Fragments. Oxford: Clarendon Press.

Nel, P J 2005. Yahweh is a Shepherd. Conceptual Metaphor in Psalm 23. Horizons in Biblical Theology. 27, 79-103.

Newman, CC, Davila, JR and Lewis, GS (eds.) 1999. The Jewish Roots of Christological Monotheism. Papers from the St. Andrwes Conference on the Historical Origins of the Worship of Jesus. Leiden: Brill.

Newsom, C 1998. Shirot Olat Hashabbat 4Q400-407, in DJD XI. Qumran Cave 4 VI Poetical and Liturgical Texts, Part 1, 173-403.

O'Connor, D and Silverman, DP (eds.) 1995. Ancient Egyptian Kingship. Leiden: EJ Brill. 
Pietersma, A and Wright, BG 2002. A New English Translation of the Septuagint. USA: Oxford University Press Inc.

Rofe, A 1979. The Belief in Angels in the Bible and in Early Israel. Jerusalem: Makor Publishing Company.

Sanderson, JE 1997. DJD. Qumran Cave $4 X(X V)$. The Prophets. Oxford: Clarendon Press.

Silverman, DP 1995. The Nature of Egyptian Kingship, in O'Connor and Silverman 1995, 49-92.

Strudwick, NC 2005. Texts from the Pyramid Age. Atlanta: Society of Biblical Literature.

Tobin, VA 1989. Theological Principles of Egyptian Relgion. New York/Bern/Frankfort am Main/ Berlin: Peter Long.

Uehlinger, C and Trufaut, SM 2001. Ezekiel 1, Babylonian Cosmological Scholarship and Iconography: Attempts at Further Refinement. Theologische Zeitschrift 2001, 140-171.

Zeigler, J 1977. Septuaginta Vetus Testamentum Graecum. Vol XVI, pars 1 Ezekiel. Göttingen: Vandenhoeck \& Ruprecht. 